\title{
Investigating Features of Multilingualism in Ayoade Okedokun's Mopelola: The Tale of a Beauty Goddess: A Sociolinguistic Appraisal
}

\author{
Innocent Sourou Koutchadé \\ Dept. of English, Abomey-Calavi University \\ PO Box 2879, Abomey-Calavi, Republic of Benin \\ Tel: 229-9651-8643E-mail: koutchade2@yahoo.fr
}

Received: December 2, 2020 Accepted: December 22, 2020 Published: December 26, 2020

doi:10.5296/elr.v6i2.18112ＵRL: https://doi.org/10.5296/elr.v6i2.18112

\begin{abstract}
In most African writings, it is commonly noticed that culture and linguistic background affect the creation of literary idiolects. African writers use the English language in accordance with the situation in which they find themselves; they also make use of multilingual features, thus combining the English language with the linguistic resources they draw from their mother tongue. This paper aims to explore patterns of multilingualism in Mopelola: The Tale of a Beauty Goddess, a play produced by a Nigerian writer, Ayoade Okedokun. The paper mainly focuses on the linguistic and cultural influence of Yoruba that reflect the use of multilingualism features in the play. The analysis shows that there are various instances of borrowing, code-switching and transliteration representing the cultural interferences which are used to accommodate some elements of the writer's native culture and language into the English language.
\end{abstract}

Keywords: Multilingualism, Yoruba, Borrowing, Code-switching, Transliteration, Mopelola

\section{Introduction}

West African creative writers use various linguistic and aesthetic devices to convey their messages and reflect their world-view. Most of the scholars in this literary arena, notably writers who produce their work in English, are mostly concerned with emphasizing their culture and traditions. To disclose their identity and cultural ideology, they use the English language but draw most of their rhetorical strategies from their mother tongue. This situation leads them to use patterns of multilingualism in their works. As observed by Adejare (1992), "the representation of African speech form in literature in English is a common feature of the 
works of several African writers in English. Traces of African mother tongues can be found in most works of these writers who are either bilinguals or multilinguals" (p.192). In the Nigerian context, the representation of indigenous language for literary purposes has, for a long time, been a reality as many writers have deliberately adopted this strategy to single out their idiolect. In this respect, Banjo (1996) contends that all Nigerian writers have to make the English language carry the weight of their African experience. In very general terms, they do this through a careful selection of structures and through a legitimate manipulation of the lexico-semantic possibility of the language.

This paper focuses on the analysis of some multilingual patterns in Okedokun Ayoade's play entitled Mopelola: the Tale of a Beauty Goddess. Most specifically, it aims to explore various features of oral literature in Yoruba culture which have been adapted in the language of the play.

\section{Literature Review and Theoretical Framework}

\subsection{Language, Culture and Social Context}

Language is culturally transmitted from one generation to another (Yule, 2007; McGregor, 2009). Culture impacts the way people use language. They display cultural difference through their behaviour, reaction, action and their communication. Hudson (2003) opines that culture refers to some characteristics shared by a community, especially those which might distinguish it from other communities. Each society displays various forms of culture and different languages are used for communication. He (Hudson, 2003) further argues that "each language will have words to express most concepts relevant to the culture, and that most words in each language will express cultural concepts, definable only in terms of the culture concerned" (p. 9). This is why Yule (2007) advocates that different groups have different languages, they have different views which are reflected in their languages. So, language use is culture-dependent and it discloses the beliefs of a given society. In this respect, Lyons (2009, p. 312) argues that there are many differences of both grammatical and lexical structure which can be correlated with differences in the cultures with which particular languages are associated.

In addition, language and context are related in that the understanding of an utterance in a given language depends on the context in which it has been used. Van Dijk (2008) quoted by Paltridge (2012) contends that "context is a subjective construct that accounts not only for uniqueness of each text but also for the common ground and shared representations that language users draw on to communicate with each other" (p. 3). On her part, Eggins (2004) stresses the link between language and context by saying that our ability to deduce context from text is one way in which language and context are interrelated. Our equally developed ability to predict language from context provides further evidence of the language /context relationship ... Final evidence which emphasizes the close link between context and language is that it is often simply not to tell how people are using language if you do not take into account the context of use." (p. 8).

From the above statement, it becomes necessary to understand that the peculiarity noticed in a literary text can be unravelled when readers are aware of the contextual backgrounds surrounding the production of that piece of discourse. In Systemicists' views, context is 
broken down into cultural context and situational context. In this regard, "the actual choice a person makes from the options that are available to them within a particular context of culture, thus, takes place within a particular context of situation, both of which influence the use of language in a text" (Paltridge 2012, p. 3). Context of culture is referred to as genre that is "a set of texts that share the same socially recognised purpose and which, as a result, often share similar rhetorical and structural elements to achieve this purpose" (Paltridge, 2012, p. 242). As for context of situation, it is also known as register, "a set of linguistic choices associated with a particular situation" (p. 13). McGregor (2004) argues that we speak of different registers or registerial variation where variation in language depends on the more immediate context of the utterance rather than characteristics of the speaker. There are three elements that specify the register of a given language. They include: the field, what language is being used to talk about, the mode, the role language is playing in an interaction, and the tenor, which refers to the role relationship between the interactants (Eggins, 2004, p. 90). From all the above arguments, we can conclude that culture plays a very important role in the interpretation of both utterances, in general and literary texts, in particular. Context is also useful in decoding the meanings of utterances in a multilingual environment. The next section focuses on the concept of multilingualism.

\subsection{Multilingualism}

When people from various geographical areas, with various linguistic groups come together, their interaction results to multilingual communities, a speech community in which two or more languages can be spoken. Multilingualism has to do with the use of several languages. Mbisike (2007) contends that it is "bilingualism on a higher level because it is just the addition of one or more languages to the ones the bilingual already has. In other words, multilingualism is the ability of an individual speaker to speak multiple languages; multilingualism is another form of language contact" (p. 189). In the same vein, Finegan (2008) opines that in a multilingual community, children grow up speaking several languages. The use of each language is often compartmentalised, as when one is used at home and another at school or at work. He argues that multilingualism is such a natural solution to the problem of language contact that it is extremely widespread throughout the world.

In fact, in a multilingual community, the choice of the language is dependent upon the context and the nature of the discussion, the identity of the interlocutor and the subject matter of the discussion. This is the reason why Wardhaugh (2010) opines that "context determines language choice. In a society in which one or more language (or variety) is used you must find out who uses what, when and for what purpose if you are to be socially competent. Your language choices are part of the social identity you claim for yourself" (p.93). In the context of the West African literature, most of writers disclose their cultural identities through the choices they make in the way they use the English language. As viewed by Banjo (2016) "the writer's style is obviously partly an expression of his personality, as well as a reflection of the complexity of his subject matter" (p. 129). This search of identity has brought scholars to "nativise" or "indigenise" the English language in their work. According to Finegan (2008), nativisation takes place "when a community adopts a new language (in addition to its native language) and modifies the structure of that new language, thus developing a dialect that becomes characteristics of the community" (p. 453). This concept is also referred to as 
"indigenisation". Multilingualism effect has brought about such linguistic phenomena of language varieties as code-switching/code mixing, borrowing and transliteration. These linguistic features are studied in the present paper.

\subsubsection{Code-Switching/Code-mixing}

In multilingual environments, people use different codes to communicate. Code- switching is a common phenomenon in which people who share more than one language get together and use two or more languages to communicate (O'Grady et al., 2011). Fromkin et al. (2011) contend that it is a speech style unique to bilinguals/multilinguals in which fluent speakers switch languages between or within sentences. For that purpose, McGregor (2010) accounts for the use of code-switching in certain situations. He says:

In many bilingual situations the languages in the speaker's repertoires include one or more local or minority languages associated with local ethnic groups, and a majority language that has no such local associations such as national or international language...Broadly speaking, choice of the local language underlines solidarity between the conversational partners, while choice of the national language serves a distancing function, emphasizing the social distance (p. 169).

On his part, Wardhaugh (2010) says that code-switching occurs in conversation between speakers' turns or within a speaker's turn. It can occur inter-sententially, that is between sentences and intra-sententially, that is within a single sentence. There are two categories of code-switching (Hudson, 2003; Wardhaugh, 2010; Holmes, 2010): metaphorical code-switching and situational code-switching. In metaphorical switching, "each of the code represents or symbolises a set of social meanings and the speakers draws on the associations of each, just as people use metaphors to represent complex meanings" (Wardhaugh 2010, p. 42). As for situational code-switching, the switches occur according to the situation in which interactants find themselves; "the choice of language is controlled by rules, which members of the community learn from their experience, so these rules are part of their total linguistic knowledge" (Hudson, 2003, p. 52).

\subsubsection{Borrowing}

Borrowing is the incorporation of an item from one language to another. It occurs when one language adds a word or morpheme from another language to its own lexicon Fromkin, et al. (2011, p. 505). Holmes (2010) accounts for the use of borrowings by saying that:

people may also borrow words from another language to express a concept or describe an object for which there is no obvious word available in the language they are using. Borrowing of this kind involves generally involves single words-mainly nouns- and it is motivated by lexical need. It is very different from switching where speakers have a genuine choice about which words or phrases they will use in which language (p. 44)

Types of borrowings include:

Loan-words: Words that are borrowed from another language.

Loan translation/ calques: These are special types of borrowing in which the morphemes composing the source word are translated items by items (McGregor, 2010, p. 89)

Loan- blend: A situation where the borrower imports parts of the model and replaces some of it with something which exists in the language. 


\subsubsection{Transliteration}

Transliteration is the conversion of one writing system into another (Crystal, 2008). Yeibo (2011) observes that the term involves the replacement of each source language word or other units with the units of the target language. On his part, Ademola (2005) argues that there are three steps to set up a transliteration system. First, the source language letters are replaced by source language phonological units. This is the normal literate process of converting from the written to the spoken medium. Second, the source language phonological units are translated into target language phonological units. Finally, the target language phonological units are converted into target language letters or other graphological units.

As for Wolson (2006), she refers to transliteration as pragmatic transfer, i.e., the use of rules of speaking from one's own native speech community when interacting with the host speech community or simply when speaking or writing in other language. As observed by Clyne (1977) cited by Wolfson (2006), pragmatic transfer occurs very similarly to the transfer of phonological, semantic, and syntactic rules and such transfer can have a major effect on the interactions of interlocutors.

\section{Method}

As said earlier, this paper aims to examine the overall sociolinguistic features of the play in order to make some conclusions about the writer's literary idiolect. Before any attempt of analysis it becomes necessary, for clarity sake, to provide a contextual summary of the play. In fact, the play Mopelola: The Tale of a Beauty Goddess is published by Ayoade Okedokun in 2008. In this play, culture and tradition are overemphasised as it is set in the traditional Yoruba village. This is clearly expressed through the name of the different characters of the play. Their belief is centred on Olodumare, the supreme God who has sent his messenger Orunmila, the father of Ifa, Orunmila, the oracle, to deliver his message to his people. Other gods include Esu, Sango, Oya, Osun, Obatala. The play is about the goddess of beauty, Mopelola, who once reigns. Her father, king Folagbade of Ikimoko kingdom has suffered many years of childlessness despite the fact that he has married fifty wives. Fortunately, the first wife has been visited by the oracle Orunmila. She becomes pregnant and gives birth to Mopelola. Just like the oracle has said it on her outing rituals, she grows up to become the only beautiful princess of the kingdom. As the only child of the palace, the entire family has thought that she will benefit by all the care she deserves. Surprisingly, Mopelola turns her back to all these privileges and decides to challenge men in all areas of life including economic, political and social. First, she decides to destroy the Olugbodi kingdom that is used to raiding their land. She rejects her marriage with Prince Tella, King Olugbodi's son and organises the warriors to defeat the whole kingdom, which she has done successfully. She then returns from the war with the beaded crown she seized from Olu of Olugbodi and wears it to declare another war against her father. She attempts to dethrone her father and this causes the king to kill himself. The king finally dies and Mope becomes the queen. During her reign, there is prosperity, wealth and abundance. Ikimoko kingdom has been the centre of business as people come from far and near to trade in the kingdom. Mopelola is known as "the queen of wealth, the goddess of beauty, the dazzling gazelle that strikes like thunder" (Ayoade, 2008, p. 101). In spite of the great prosperity and happiness that prevails in the 


\section{Macrothink

kingdom, the people of Ikimoko remain unsatisfied as the queen is yet to give birth to a prince or princess that will inherit the good fortune of the throne. As Mopelola, the queen cannot find a suitable man to father her and give her a super prince or princess, she decides to refer to Baba Awo, the Ifa priest who consults the oracle and recommends that Mopelola carry a sacrifice to the deep forest in the middle of the night. She goes to the forest in the world of the spirits where she has been deflowered. The queen gets pregnant and gives birth to a white baby. This is viewed as an abomination and the baby has to be thrown to the evil forest. Mopelola abandons the throne, her wealth everything and follows her child to the forest. Finally, Mopelola, the epitome of love, the paragon of beauty, the embodiment of hope the symbol of freedom has departed the land for the deep forest where the prince has lived and grown up to father a generation which is known as the white race of today.

To carry out the analyses and discuss the results, the play has been studied thoroughly. The research design is descriptive and based on qualitative approach. Prominent linguistic elements of multilingualism have been identified in some passages of the play. They have been selected, numbered and written in italics.

\section{Results of the Study}

It is noteworthy to mention here that some important linguistic data are identified and analysed.

\subsection{Analysis of Borrowing in the Play}

Features of borrowing occur in this play and categories of them such as loan-words and loan blends that have been identified are listed below:

(1) We thank Olodumare the Supreme Being........ (p. 7)

(2) Kabiyesi, you are the father of the child........ (p. 7)

(3) Orunmila, the short granddad, with belly wisdom, answer us. (p. 8)

(4) ......Ejiogbe, the king of the corpus (p. 8)

(5) A-se-e (p. 14)

(6) This is moi-moi...... (p. 28)

(7) kere o! kere o! kere o! (p. 43)

(8) Baba said that we should still use them (p. 59)

(9)..... but the day he killed orangbankogbi, the father of all troubles....

(10) Esu, Sango, Oya, Osun, Obatala and all the gods of our land (p. 71)

(11) Where are you rushing to in flowing agbada? (p. 104)

(12) Ago onile o, your highness (p. 107)

(13) Oyibo, what does that mean? (p. 122)

(14) ........and seven heads of agama lizard (p. 58)

(15) It was thrown in oro grove as well as with heavy sacrifice (p. 120)

(16) Apena, inform oro cult to purify the land while I made my decision (p. 100)

As can be noted above, all the instances of borrowing are Yoruba words used by the playwright in his work. They have not been glossed over by the writer and any non-Yoruba 
reader will find it difficult to understand their meaning and their context of use.

\subsection{Analysis of Transliteration}

The "africanization" of the English language for literary purposes is also noticed through the transliteration of African realities into English. They include the Yoruba popular sayings, riddles, proverbs and aphorisms in English, the transliteration of some instances of everyday language and the transliteration of sacred language into English.

\subsubsection{Transliteration of Proverbs/Sayings in English}

Proverbs, sayings, as well as popular idioms in Yoruba are transliterated into English throughout the play. Some of them are selected and analysed below:

(16) He who tarries to take his food will eat with a golden plate. (p. 16)

(17) Who announces the birth of a new moon to the world? (p. 16)

(18) Mother, any bird that attempts to droop like a bat will vomit blood. (p. 21)

(19) The secret of the snake is its belly. (p. 24)

(20) The finger that sizes the nose is the appropriate one to clean it. (p. 26)

(21) Even if you don't know the elephant, its shout should not be strange to you. (p. 34)

(22) The son of a monkey will always expose the ugliness of its father. (p. 34)

(23) We ask for a master carver, a woodpecker bird jumped down from the tree. (p. 34)

(24) Every grass cutter calls itself meat; I wonder what an elephant would be called?(p. 35)

(25) The head of a newborn baby should not be out of proportion where there are elders. ( $p$.

(26) The crab makes use of its eyes to watch over its head. (p. 43)

(27) The monkey has never refused the challenge of tree climbing. (p. 50)

(28) The head of an elephant is beyond the old a kid can carry. (p. 52)

(29) This is a very hot soup you don't lick it in haste. (p. 54)

(30) For like today tomorrow may not be, thus make the priest to consult oracle daily. (p.56)

(31) An old man that is running inside the bush, if he's not pursuing something, definitely something is pursuing him. (p. 56)

(32) If we give a fool the chance to think, he may pick sense. (p. 66)

(33) Where the chameleon feeds, ants must keep distance. (p. 67)

(34) A man with leprous hands buys groundnut and you ask him to take more as dash, has he got the hand to carry the original he bought? (p. 77)

(35) Nobody challenges the monkeys on the tree top. (p. 80)

(36) On the destined day of the monkey's death, every tree becomes slippery. (p. 82)

(37) Don't appeal to a man under epileptic attack to deep his hand inside fire, nor appeal to a man with elephantiasis to put his leg inside the colony of soldier ants. (p. 88)

(38) Even the bush that said the elephant will not cross the valley has had its roots dragged across the river. (p. 92)

(39) He who has no ears will dismiss the chatter of a weaver bird as a mere noise. (p. 97).

(40) He who wants to harvest the honey inside the rock must not complain about his axe. (p. 
109)

(41) A dog will not leave and leave behind the bells on its neck. (p. 123)

(42) A Pigeon never deserts its owner in time of trouble. (p. 123)

It can be noticed that these identified sentences reveal that the Yoruba language is full of images, symbols and proverbs. Although they are written in English, their deep meanings can only be decoded by natives who are rooted in the Yoruba culture. In Africa, proverbs are used as words of wisdom. In this regard, only elderly people are allowed to use them.

\subsubsection{Transliteration of Everyday Language in English}

Apart from the transliteration of images, proverbs and common sayings, there are instances of everyday language which are imported from the Yoruba language into English. Here are a few of them:

(43) My mouth is not as loose as that" (p. 25)

(44) I have your father under my feet" (p. 35)

(45) Only the unpolluted flowers can touch it" (p.45)

(46) I have never known any man" (p. 45)

(48) You have climbed my chest" (p. 117)

In everyday language, the Yoruba people have the ability to code their language especially in specific situations. Their proper interpretation has to be carried out in their cultural and situational context of use.

\subsubsection{The Transliteration of Sacred Language into English}

This play also displays patterns of the language of divination. In the context of this plays, they occur when they ask the Ifa priest (known as Baba-Awo here) to consult the oracle. This is carried out through a divination chain that Baba-Awo throws down and observes. In this paper, some aspects of this sacred language have been selected and italicised below:

(49) This is how they did for Olugbon that made his life smooth, they did it for Aresa; the palm-oil magnate, his life knew no evil, the same for Orangun; the palm-wine taper and his life was as sweat as honey. (p.8)

(50) Thus divined for Wealth when he went to the oracle to ask for children. It was wealth that gave birth to Winbolu. Winbolu was born with wealth, Winbolu was born with beauty. She got wealth, wealth and fame. Fame and beauty. Then the people said 'what is this' we don't know'. The oracle then replied it is because you lack knowledge. Knowledge and wisdom to know. Don't you know that the beauties are proud? Winbolu was the king but she refused to get married. Winbolu refused the elephant of the forest; she refused the buffalo of the jungle but only the spirit of the iroko tree. (p. 10)

(51) Ifa you know I don't know, you see I don't see. You have the knowledge I am but a novice. You know what she discussed with you. Tell me exactly as it is. Don't talk yes for no. Don't talk evil for good or good for evil. Don't stammer nor hide the truth. Say everything as it is. Blow off the veil in my eyes I want to see. (p. 56)

(52) Ika corpus. Chief Aro of Ika land must not eat dog. Chief Odofin must not eat ram, likewise it is forbidden for the Ejemu of Ika to eat he-goat and the overall head of the whole clan must not taste dog head. Adjust your hands for me I will adjust my legs, so a weaver 


\section{Macrothink}

moves round the pegs. Their mother bears Akaagbon, their father Akaagun, the youngest Akaakaakawo and their eldest akaakagbasa. Thus divined for Sabamo when he went for counsel from priest Onikaamogun. The oracle then asked them why they were bearing such difficult names? They answered 'for we are not well able to conquered the world'. The priest then appeased the oracle on their behalf to help them conquer the world. (p. 57)

(53) Orunmila, the way we divine for a non-initiate. You're the initiator we only follow you to bear the name. Ifa, we are at a cross-road, show us the way. (p. 95)

As a matter of fact, the language of Ifa divination is coded and learned through formal and serious initiations. It comprises incantations and symbols which are uttered during the divination processes.

\subsection{Code-Switching in Okedokun Ayoade's Mopelola}

In this play, Yoruba rhetoric is also exemplified through the use of code-switching in the play. The peculiarity of this literary artifact is that features of code-switching represent some various forms of Yoruba poetry. In addition, depending on their context of use, most of these features have been transliterated into English by the writers. Some of them have been revisited in table 1 below:

Table 1. Code-switching in the play

\begin{tabular}{|c|c|c|}
\hline No & Code-Switching & English translation as suggested by the writer \\
\hline 54 & $\begin{array}{l}\text { Omo ni koko aye o } \\
\text { He he e } \\
\text { Omo ni koko aye } \\
\text { Biya rogun aran fun mi ko je } \\
\text { nnkan } \\
\text { Omo ni koko aye } \\
\text { Omo ni ko bami je o -he he e } \\
\text { Omo ni ko ba mi (p. } 7)\end{array}$ & $\begin{array}{l}\text { Children are the essence of life } \\
\text { The twenty special cloth mother bought for me are } \\
\text { nothing } \\
\text { Children are the essence of life. } \\
\text { Eating it with my children I pray } \\
\text { If okra without salt is the only soup I can afford (p.7) }\end{array}$ \\
\hline 55 & $\begin{array}{l}\text { Omode o foju bodu lassan } \\
\text { Agba o foju bodu lofee } \\
\text { Beeyan ba foju bodu yoo } \\
\text { dawo } \\
\text { A difa fun Orunmila } \\
\text { Nijo to n sawo rode Ijan } \\
\text { Won ni bo ba ti foju bodu } \\
\text { Orin ni ko maa ko } \\
\text { Awa foju bodu a rire o } \\
\text { Awa foju bodu a rire } \\
\text { Awa foju bodu a o ku mo }\end{array}$ & $\begin{array}{l}\text { A child beholds not the oracle just for fun } \\
\text { An elder beholds not the oracle for free } \\
\text { Whoever beholds the oracle must be initiated } \\
\text { Thus divined for } \\
\text { The day he was on a journey to Ode Ijan } \\
\text { He was told to sing whenever he beholds the oracle } \\
\text { We behold the oracle, we behold good things } \\
\text { We behold the oracle, we behold good things } \\
\text { We behold the oracle, we die no more } \\
\text { We behold the oracle, we behold good things } \\
\text { Kabiyesi, I behold a king. (p. 9) }\end{array}$ \\
\hline
\end{tabular}




\section{Macrothink}

\begin{tabular}{|c|c|c|}
\hline & & \\
\hline 56 & 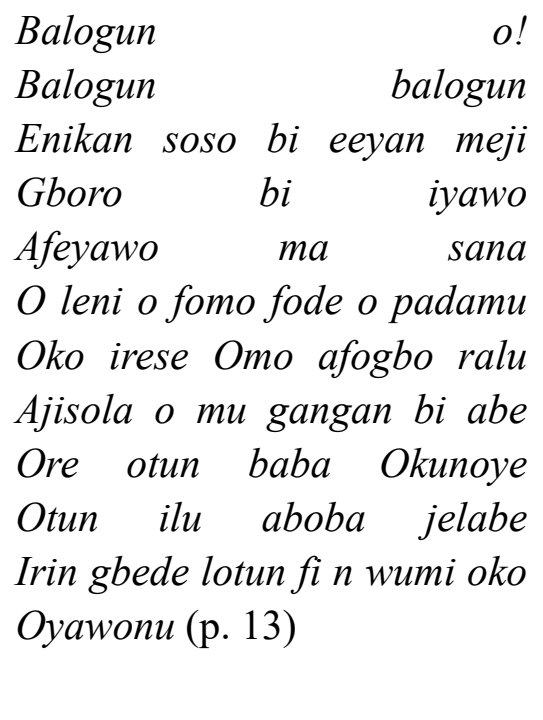 & $\begin{array}{l}\text { Chief Balogun, a war } \\
\text { General in war, general in charms } \\
\text { One man like two, elegant like a bride } \\
\text { He who married and paid no dowries } \\
\text { It is said that he who gives a wife to a hunter loses } \\
\text { nothing } \\
\text { General at home general at war } \\
\text { The descendant of Ajisola, you're as sharp as a razor. } \\
\text { The of Chief } \\
\text { Otun the right-hand-man of the king that eats the } \\
\text { choicest. } \\
\text { In giant stride Otun you caught my admiration, } \\
\text { The only husband of Oyawonu. (p. 13) }\end{array}$ \\
\hline 57 & $\begin{array}{l}\text { Okunrin ti o da mi loko owo } \\
\text { Ko ma le pori mi lo daru } \\
\text { Bo ba pe mo fonu (twice) } \\
\text { Emi naa a si lori e lo faya (p. } \\
\text { 20) }\end{array}$ & $\begin{array}{l}\text { A man that does not set me up in business } \\
\text { Cannot } \quad \text { tell } \quad \text { me } \\
\text { If 'am }\end{array}$ \\
\hline 58 & $\begin{array}{l}\text { Laye olugbon mo da borun } \\
\text { meje } \\
\text { E o ma fiwe lorin } \\
\text { Laye areas mo daborunmefa } \\
\text { E o ma fiwe lorin } \\
\text { Laye aremu mo ra koko mo } \\
\text { raran } \\
\text { Mo ra sanyan baba aso } \\
\text { Afole, afole, eni pele yi o dun } \\
\text { Ko ya keru soko-(p. 28) }\end{array}$ & $\begin{array}{l}\text { During the reign of olugbon, I had seven good clothes } \\
\text { In that of Aresa, I had six } \\
\text { Please mind } \\
\text { In this reign of Aremu, I have koko; } \\
\text { I have bought aran and sanyan the father of clothes. } \\
\text { Whoever says this era is not favourable } \\
\text { Must be very lazy, lazy I said } \\
\text { Let him pack his luggages and go elsewhere (p.28) }\end{array}$ \\
\hline 59 & $\begin{array}{l}\text { Maa rin maa yan } \\
\text { Omo-oba lo } \text { nile } \\
\text { Lo nile lo nile loni le } \\
\text { Omo oba lonile--- (p. 33) }\end{array}$ & $\begin{array}{l}\text { Walk with } \\
\text { The leisure } \\
\text { Owns the land, owns the land, owns the land } \\
\text { The prince owns the land (p. 33) }\end{array}$ \\
\hline 60 & $\begin{array}{l}\text { Pa bi osan ja } \\
\text { Osan ja awo won lode itori } \\
\text { Atanpo jakun o dobiri kale } \\
\text { A dia fun Orunmila } \\
\text { Nijo ti } n \text { lo ree taye Olufe-oro } \\
\text { so } \\
\text { Bi eni sogba. }(\text { p. } 58)\end{array}$ & $\begin{array}{l}\text { You see, pa-bi-osan-ja the priest of Itori and Atampo } \\
\text { jakun, the divined for Orunmila himself the day he was } \\
\text { called to mend the destiny of Olufe Oro. They asked } \\
\text { who will mend it just like a broken calabash. (p. } 58 \text { ) }\end{array}$ \\
\hline 61 & boju & wants \\
\hline
\end{tabular}




\section{Macrothink}

\begin{tabular}{|c|c|c|}
\hline & $\begin{array}{l}\text { O fe fata boju } \\
\text { Mopelola } \\
\text { Ofe fata boju } \\
\text {--- (p. 64) }\end{array}$ & Mopelola the braggart. (p.64) \\
\hline 62 & $\begin{array}{lrrrr}\text { A feni ti } & \text { kogila } & \text { kolu } \\
\text { A feni } & \text { esu } & \text { ose } \\
\text { Lo le ko } & \text { ko } & \text { Esu } \\
\text { Lo le ko lu } & \text { Sango } \\
\text { Afeni kogila o kolu-(p.65) }\end{array}$ & $\begin{array}{l}\text { Unless he who wants to be hit with calamities } \\
\text { Unless he who wants to be hit by evils } \\
\mathrm{He} \text { alone can dare Esu (the dreaded god) } \\
\mathrm{He} \text { alone can dare Sango (the god of thunder) } \\
\text { Unless he who wants to be hit by calamities. (p.65) }\end{array}$ \\
\hline 63 & $\begin{array}{lrr}\begin{array}{l}\text { Muso! } \\
\text { Bogun }\end{array} & & \\
\text { Bo ba fana } & \text { soju } \\
\text { Bo ba ba dogun } & \text { koko } \\
\text { E } & \text { ke si Mopelola } & \text { (p.72) }\end{array}$ & $\begin{array}{l}\text { If war is hot } \\
\text { If it becomes a fight } \\
\text { If it becomes a raging war } \\
\text { Just call Mopelola. (p.72) }\end{array}$ \\
\hline 64 & $\begin{array}{l}\text { Won sese a juwon' lo na o } \\
\text { Won sese a juwon lo na } \\
\text { Igba orore o tokan aparo } \\
\text { Won sese a ju won lo na } \\
(\mathrm{p} .86)\end{array}$ & $\begin{array}{l}\text { We've defeated them despite all their aggressions } \\
\text { We've defeated them despite all their aggressions } \\
\text { A thousand of their sparrows worth not our single quail } \\
\text { We've defeated them despite all their aggressions). } \\
\text { (p.86) }\end{array}$ \\
\hline 65 & $\begin{array}{l}\text { Oko wa ni o } \\
\text { Baba wa ni } \\
\text { Mopelola alawo kete o } \\
\text { Baba wa ni-(p. 89) }\end{array}$ & $\begin{array}{l}\text { She's our husband } \\
\text { She's our father } \\
\text { Mopelola Alawo kete } \\
\text { She's our father. (p.89) }\end{array}$ \\
\hline 66 & $\begin{array}{l}\text { Ta lopa o loba tia } \\
\text { Kai, a loba tia } \\
\text { Mopelola wa } \\
\text { Kai a loba tia-(p. 89) }\end{array}$ & $\begin{array}{l}\text { Who said we don't have our own king? } \\
\text { What, we have our king } \\
\text { Mopelola is our king } \\
\text { What, we have our king. (p.89) }\end{array}$ \\
\hline 67 & $\begin{array}{l}\text { Kin le } n \text { foba pe } \\
\text { Oba o oba alase oba } \\
\text { Oba toto bi aro } \\
\text { Oba o oba alase oba } \\
\text { Oba rere bi osun } \\
\text { Oba o oba alase oba---(p. 90) }\end{array}$ & $\begin{array}{l}\text { What do you call king? } \\
\text { The king is the king of authorities } \\
\text { The king as deep as deep as dye } \\
\text { The king as bright as cam-wood. (p.90) }\end{array}$ \\
\hline 68 & $\begin{array}{l}\text { Ode ma pami tere } \\
\text { Tere alumonja } \\
\text { Alumonja alumonja alumonja } \\
\text { tere o } \\
\text { Tere alumonja } \\
\text { Boo ba pami o pejo nla }\end{array}$ & $\begin{array}{l}\text { Hunter don't kill me } \\
\text { Don't kill me } \\
\text { If you dare kill me } \\
\text { You kill the biggest of the snakes } \\
\text { If you dare kill me } \\
\text { You kill oluremi the most beautiful of the snakes. (p. }\end{array}$ \\
\hline
\end{tabular}




\begin{tabular}{|c|c|c|}
\hline & $\begin{array}{l}\text { Tere alumonja } \\
\text { Boo ba pami o p' oluremi } \\
\text { arewa ejo } \\
\text { Tere alumonja } \\
\text { Alumonja alumonja alumonja } \\
\text { tere o } \\
\text { Tere alumonja. (p. } 94)\end{array}$ & 94) \\
\hline 69 & $\begin{array}{l}\text { Emi o mobi olori gbe n yanri } \\
\text { o } \\
\text { N ba lo yan temi } \\
\text { Ibikan naa la gbe yanrio } \\
\text { Kadara o papo ni (p.100) }\end{array}$ & $\begin{array}{l}\text { I know not where destines are chosen. } \\
\text { I would have gone and chosen my own. } \\
\text { We choose the same destiny only fate makes the } \\
\text { difference. } \\
\text { Truly, Mope chose the best destiny and her own has so } \\
\text { influences that of others. Life was so easy for } \\
\text { everybody and there was prosperity, wealth } \\
\text { everywhere. } \\
\text { (p. 100) }\end{array}$ \\
\hline 70 & $\begin{array}{l}\text { Ogede ki } i \text { so leemeji } \\
\text { Mopelola } \\
\text { Bere re le tan } \\
\text { Iwo nikan ni o ku o--(p.109) }\end{array}$ & $\begin{array}{l}\text { Plantain bears fruit but ones } \\
\text { If your joke turns to another thing } \\
\text { You'll be left alone to it. (p. 109) }\end{array}$ \\
\hline 71 & $\begin{array}{l}\text { Oro abosi lona odo o } \\
\text { Oro abosi lonan odo bobinrin } \\
\text { o sabosi won a gbagbe odo } \\
\text { Oro abosi lona odo (p.115) }\end{array}$ & $\begin{array}{l}\text { Gossip on their way to the river } \\
\text { When women want to gossip they pick up their gourds } \\
\text { for water. } \\
\text { Gossip on their way to river. (p.115) }\end{array}$ \\
\hline 72 & $\begin{array}{l}\text { Agbe tori omo re daro o } \\
\text { Olele } \\
\text { Aluko tori omo re kosun o } \\
\text { Olele } \\
\text { Iya akoko tor' omo re ragogo } \\
\text { ide o } \\
\text { A ko le saro iwonyen } \\
\text { E mo o molu sere o } \\
\text { Olele. (p.124) }\end{array}$ & $\begin{array}{l}\text { The black wood-cock bird chose to dye itself all black } \\
\text { Just for the safety of its chicks. } \\
\text { The red-wood cock bird chose to dye itself red } \\
\text { Just for the safety of its chicks } \\
\text { The mother wood-pecker chose a silver beak } \\
\text { Just for the safety of its chicks } \\
\text { Just not of the crown. (p.124) }\end{array}$ \\
\hline
\end{tabular}

It can be noticed from the above table that features of Yoruba songs used in the book have been transliterated into English. These are songs that are used by some characters of the play. Songs are also parts of oral literature in Yoruba tradition. Viewed from their cultural context, they are used to convey specific messages and display various linguistic imports. 


\section{Discussion}

The previous section has focused on the linguistic features that exemplify the multilingual aspects of the play under study. They include borrowing, transliteration and code -switching. This section aims to revisit some aspects of them. First, it can be noticed that all the borrowed items used in the whole text are drawn from the Yoruba language. In fact, the traditional belief in Yoruba is that The Almighty God, also referred to as Olodumare in (1) is the creator of everything and he deserves praises and worship in special occasions as in when Kabiesi, which means "your highness" (the King) in (2) has been favoured by a new baby girl (Mopelola) after many years of bareness. In this traditional context, the use of the borrowed word Orunmila in (3) implies that the whole community is rooted and submitted to the message of the Oracle, Ifa (also referred to as Orunmila), who is divined shortly after in order to know more about the becoming or future of the baby. According to Adegboyega (2017)

If $a$ has been defined as a divination system, as an alternative name for its prophet, Orunmila, a name given to the religion of the Yoruba people in present day Nigeria, and more besides. It touches all of these but, at its heart, Ifa is about the power of wisdom to approach the mysterious and, through this, to offer an understanding of the visible and invisible worlds through which our lives, collective and unique, are made accessible. (p.30, my emphasis)

Edjiogbe used in (4) is one the sixteen major corpus of Ifa. A particular way of saying "Amen" (So shall it be) in Yoruba is Ase-e, used in (5).

Moreover, when there is a particular situation which prompts the king to inform the whole community, he instructs the town crier to deliver the message to his community. To call people attention, the latter uses the onomatopoeic words Kere o! Kere o! Kere! as in (7) to call the attention of the people to the king's message. While Baba in Yoruba means "old man" in (8), orangbankogbi in (9) is a type of animal. More importantly, apart from the supreme God Olodumare and Orunmila that are venerated, Yoruba traditional societies also rely on deities which are mentioned in (10) including Esu, a protective, benevolent spirit who serves Ifa. He is a messenger between heaven and earth, Sango, the Yoruba god of thunder and lightning, Oya, the Yoruba goddess of storm, Osun, goddess of river Obatala, the Yoruba creator God. The loan word "agbada" in (11) is used by the writer to foreground the traditional flowing gown for men. Likewise, a special greeting before entering the king palace is compulsory and it is phrased in (12) as ago onile o to mean "greetings in the house". In (13), (14), (15), words are borrowed from Yoruba and combined with others in English to form a specific meaning.

Regarding the use of transliteration in the play, the above proverbs and images translated into English "retain the vivid imagery and culture of the Nigerian Language" (Igboanusi, 2004, p. 229). Most specifically, they "indicate to the reader that the characters in whose dialogue they occur use Yoruba and not English" (Adejare, 1992, p.182). In that regard, in (16), Balogun, one of the characters is highlighting the reward of the King's patience during his long period of childlessness. At long last, he has been blessed with a princess of wealth, Mopelola. This proverb actually means that there is reward in patience. When the new princess is born, people come from various places to pay homage to the new princess, which surprises the king himself because he has not informed them. To reply to him, one of his ministers uses the 
image in (17) to mean that everybody in the community is aware of whatever happens in the palace. The proverb used by Mopelola in (18) is a symbol of courage she has shown. She is sure that no one can challenge her in her intention to rule the whole kingdom as the queen. The latter will definitely get into trouble. Likewise, Mopelola is criticizing her mother for revealing her secret. She has used the proverb "the secret of the snake is its belly" in (19) to remind her mother that she has to learn to be secretive. In (20), Mopelola has used the proverb to mean that the right person should be at the right position. Likewise, item (21) is an image. Here, Prince Tella, a son of King Olugbodi has told the princess that he is so popular that everybody should recognize him. In return, Mopelola replies by the proverb: "the son of a monkey will always expose the ugliness of its father" in (22) to mean that a bad child will always disgrace his parents in every situation. She further uses the image in (23) and (24) to show Prince Tella that he is awarding himself the honor that he does not deserve. Moreover, the proverb in (25) is used by the king to show that elderly people play the role of guides to younger ones to help them avoid troubles. The proverb used by the Town Crier in (26) is an invitation of the villagers to be more vigilant so as not to fall into the trap of their common enemy, the Olugbodi Kingdom. The image used in (27) means that no one complains about the difficulties they encounters in what they do for a living. Likewise, the Olugbodi people are so powerful that everybody fears them. Even Mopelola is warned not to challenge them; to illustrate this, the proverb (28) is used to show that no one can defeat this kingdom. In (29), Mopelola is advising the man not to be in a hurry, but to act with patience because some situations require patience before taking any decision.

On the other hand, images are used to convey special messages. This is the case of the one used in (30) where Baba-Awo (the Ifa priest) has used the image to mean that nobody can predict the future and that the future may be different from the present time. Similarly, Mopelola has shown in (31) that there is a special reason that brings about someone to act in a particular way. Likewise, the image in (32) is an invitation to act fast before the opponent can find a way to react, whereas the utterance (33) means that when a leader or a powerful person talks, all his subordinates keep quiet. The aphorism used in (34) means that it is impossible for someone who has not finished handling a situation and is asked to be involved in another situation. Item (35) is used to mean that no one can challenge a person who is professionally trained in his work/ job. As for item (36), it shows that the day a man is disgraced, he will fail where he used to succeed. The image used in (37) reveals that a man who cannot feel a pain will not bother about hurting himself. The referent in this context includes the Olugbodi's warriors who do not care about anything that can stop them from destroying their enemies. The explanation of the Yoruba saying in (38) is that someone who wants to challenge a strong man will get into trouble. This refers to the Olugbodi warriors who have attempted to destroy Mope and her warrior. They finally lost the battle and have been killed. The proverb in (39) emphasizes the fact that nobody in traditional Yoruba should neglect the elderly people's warnings. Actually, after the divination, the King has been warned by Baba-Awo to make sacrifices so that two kings will not rule the kingdom, the King has not hearkened to it. But, as whatever the oracle says comes to pass, the king has to bear the consequences. Item (40) is a proverb which means that a person who seeks for a good result in whatever he/she undertakes should not complain about its constraints. It is the 
equivalent of the proverb "nothing good comes easy" in English. Mopelola has used it to acknowledge the fact that if she truly wants to have a perfect man to father her super prince or princess, this will involve very difficult situations and she is ready to endure everything. The two proverbs used in (41) and (42) are used by Baba-Awo to show her Highness Mope that he is part of her destiny. They are bound to be together whether both in time of happiness and trouble. This also shows that Good friends never deserts in hard situations. Good friends not only share comfortable moments with us, but they are also present at our sides during uncomfortable moments.

Instances of transliterated terms of everyday speech are also displayed in this play. In fact, Mopelola tells her mother that she does not speak anyhow outside the palace so that all the secrets of the palace will be revealed outside. That is the reason why she says in (43) that her mouth is not as loose as that. Furthermore, when she has severely insulted Prince Tella, King Olugbodi's son, the latter replies in (45) that he has her father under his feet; this means that the king, Mopelola's father is under the influence and authority of Prince Tella and implicitly under Olugbodi Kingdom. Furthermore, Iyaosa, a frail old woman at Ikimoko shrine forbids Mopelola to touch the lamp of life and explains in (45) that "only the unpolluted flowers can touch it" that is to say, only a virgin woman can touch it. Mopelola in turn replies in (46) that she has never known a man, which means that she is still virgin, she has never had sexual intercourse with any man. This saying is roughly similar to utterance (48): 'a woman's chest' simply means in Yoruba 'having a sexual intercourse with her'.

Features of transliteration which are realized in Yoruba sacred texts including riddles from Ifa corpus and incantations are also listed previously. The above corpuses are the language of the initiates. They are interpreted by the Ifa priest. In (49), the Ifa Priest has introduced the divination through poetry. Then, the riddle aims at pleading the Ifa to make life smooth and sweet for the newly born princess. The corpus in (50) and (53) are true examples of Yoruba rhetoric which leads the priest to the realm of divination. The past divination has been referred to in order to predict what will happen for the new princess in the future. Likewise, the preliminary chant has introduced the divination to be performed when he has been called to predict the future. This is the literal translation of Yoruba incantation pronounced by Ifa priests before he throws the divination chain (known as Opele in Yoruba) on the ground. Then to deliver the message, images are used by the priest. This is the case in (51). Here, the riddle transliterated in English appears mainly in the conquering of a power, a land, a territory and so forth. It shows that this conquering will be or even is already a success. In the play, for instance, this is shown with the victory of Ikimoko village over its neighboring one, Olugbodi village during the war led by Mopelola Asake.

As far as instances of code-switching are concerned, the above table shows that in this play, various features of songs, incantations and Ifa corpus have been displayed in Yoruba and transliterated into English. The first group here includes Yoruba songs used for war and revenge as in $(61,62,63,64)$. The warriors sing them to express courage and challenge. Other songs are used for celebration as in $(54,56,59,65,69,70)$ in $(54)$, for instance, they are used for entertainments during the celebration of Mopelola the goddess of beauty. The instances of code-switching in $(55,69,72)$ include the chant linked with the system of Yoruba divination and incantation. 


\section{Macrothink}

\section{Conclusion}

This paper has attempted to analyze a play written by a Nigeria author through the lens of sociolinguistics. The main contention is that, some instances of the native language of the writer have been imported into the language of the play which has been nativised or indigenized, thus stressing the multilingual resources of the work. Given that culture and traditions generally influence the production of African writers, the work has outlined the relationship between language, culture and contextual situations. It has, then, been argued that context influences the way language functions to express cultural and situational meanings. In this regard, "an understanding of the cultural background from which a work springs may help both reader and critic in appreciating more fully a particular work (King, 1971, p. 173).

Through the analysis, it has been revealed that instances of borrowing, transliteration and code-switching have displayed the multilingual strategies that have been adopted by the author of the play. The findings reveal that oral literature have notably influenced the production of the play and the findings of the analysis have confirmed Igboanusi (2004, p. 221)'s claim that many aspects of the texts are typical adoption of the oral style to written tradition. There is, for instance, a preponderance of figurative language and idiomatic expressions with local color in direct translation or transliteration from their mother tongue. To understand and interpret their meanings properly, one must have to understand the tradition from which they are drawn. In addition, tradition has immensely influenced this work. Features of Yoruba oral poetry such as ofo (incantations), oriki (praise poems), Ifa corpus (chants associated with the profound system of Yoruba divination corpus) are also exploited in this play for the realization of Yoruba speech and world-view in English texts.

\section{References}

Adegboyega, O. O. (2017). The metaphysical and epistemological relevance of Ifa corpus. International Journal of History and Philosophical Research, 5(1), 28-40

Ademola, O. E. (2005). Transliteration in Nigeria Literary English: The Case Study of Tutuola. Olateju, M., \& Oyeleye, L. (eds). Perspectives on Language and Literature. Ibadan: Intec Printers Limited.

Adejare, O. (1992). Language and Style in Soyinka. Systemic Text Linguistics of a Literary Idiolect. Ibadan: Heinemann Educational Books.

Akmajian, A. (2012). Linguistics: An Introduction to Language and Communication. (6th ed) New Delhi: PHI Learning Private Limited.

Ayoade, O. A. (2008). Mopelola: The Tale of a Beauty goddess. Lagos: Rhichmman Jhordan Publishing.

Banjo, A. (1996). Making a Virtue of Necessity: An Overview of the English Language in Nigeria. Ibadan: Ibadan University Press.

Crystal, D. (2015). A Dictionary of Linguistics and Phonetics. London: Blackwell Publishing. Eggins, S. (2004). An Introduction to Systemic Functional Linguistics. (2nd edition). London: Continuum.

Finegan, E. (2008). Language: its Structure and Use. US: Thomson Wadsworth. 


\section{Macrothink}

Fromkin, Y. et al. (2011). An Introduction to Language. US: Wadsworth.

Holmes, J. (2008). An Introduction to Sociolinguistics (3rd ed.) London: Longman.

Hudson, R. A. (2001). Sociolinguistics (2nd ed.). Cambridge: Cambridge University Press.

Igboanusi, H. (2004). African World-Views in Western Languages: Semantic Dislocations in African Literature. Oyeleye, L. (ed). Language and Discourse in Society. Ibadan: Hope Publications.

King, B. (1971). Introduction to Nigerian Literature. Lagos: Evans Brothers Limited.

Lyons, J. (2009). Language and Linguistics: an Introduction. Cambridge: Cambridge University Press.

Mbisike, C. R. (2005). Some Basic Sociolinguistic Concepts. In Olateju, M. \& Oyeleye, L. (Eds). Perspectives on Language and Literature. Ibadan: Intec Printers Limited.

McGregor, W. B. (2009). Linguistics: an Introduction. London: Continuum.

O'Grady, W. (2011). Contemporary Linguistics: An Introduction. London: Pearson Longman.

Paltridge, B. (2012). Discourse Analysis. London: Bloomsbury. https://doi.org/10.5465/ AMBPP.2012.11835abstract

Van Dijk (2008). Discourse and Context: A Sociocognitive Approach. Cambridge: Cambridge University Press. https://doi.org/10.1017/CBO9780511481499

Wardhaugh, R. (2010). An Introduction to Sociolinguistics. London: Blackwell Limited.

Wolfson, N. (1989). Sociolinguistics and TESOL. Cambridge: Newbury.

Yeibo, E. (2011). Nativization of English in African Literary Texts: A Lexico-Semantic Study of Transliteration in Gabriel Okara's The Voice International Journal of Humanities and Social Science, 1(13), 202-208. https://doi.org/10.5539/ijel.v1n2p213

Yule, G. (2007). The Study of Language. (2nd edition). Cambridge: Cambridge University Press.

\section{Copyright Disclaimer}

Copyright reserved by the author(s).

This article is an open-access article distributed under the terms and conditions of the Creative Commons Attribution license (http://creativecommons.org/licenses/by/4.0/). 